\title{
Analysis of Utilizing Environmental Services Around the Protected Forest Area of Ternate City
}

\author{
Aqshan Shadikin Nurdin ${ }^{1, *}$, Emy Saelan ${ }^{2}$ \\ ${ }^{I}$ Department of Forestry, Faculty of Agriculture, University of Khairun, Ternate, North Maluku, Indonesia \\ ${ }^{2}$ Department of Animal Science, Faculty of Agriculture, University of Khairun, Ternate, North Maluku, Indonesia \\ "Corresponding author. Email: aqshan@unkhair.ac.id
}

\begin{abstract}
Environmental services are products of biological natural resources and their ecosystems in the form of tangible and indirect benefits (intangible), which include natural or recreational tourism services, water/hydrology protection services, soil fertility, erosion control, and flooding, beauty, uniqueness, biodiversity, carbon sequestration, and storage. This study aims to assess the use of environmental services carried out by communities located around protected forest areas. Sampling is done using the census method. Data analysis was carried out by quantitative descriptive method. The analysis of the quality of tourism products is done by using the scoring model by giving a score. The results showed that Angus stone tourism products and Sulamadaha beach were included in Medium quality. Based on the results of observations and assessments that refer to the parameters of Bureau of Land Management, Batu Angus tourism objects were included in class B, namely 17 (Medium Quality) and Sulamadaha Beach in class A which is 18 (Medium quality). Viewed from the aspect of the quality of tourism which consists of elements of authenticity, uniqueness, beauty, integrity, and availability of land development, and institutional aspects. Although currently the management has not been maximized, it has obtained permits and support from the Forestry Service in its tourism development. In this area, the quality aspects of the tourist attraction were slightly reduced due to tourist activities such as vandalism, footpath damage, and the accumulation of garbage.
\end{abstract}

Keywords: analysis, utilization, environmental services, forest area

\section{INTRODUCTION}

Forest is a renewable natural resource and has an important role in supporting human life. This resource has a multipurpose asset in the sense that it can produce economic products from forest products such as wood and its derivatives as well as producing environmental services [1]. Environmental services are defined as services provided by the function of natural and artificial ecosystems whose values and benefits can be felt directly or indirectly by stakeholders in order to help maintain and improve the quality of the environment of people's lives in realizing sustainable ecosystem management [2].

The willingness to preserve forest and rehabilitate forests can be a willingness to pay environmental improvement funds [3]. Although the forest is no longer the main source of livelihood of the surrounding community, but the existence of the forest should be maintained primarily as an environmental service provider that can not be ignored its importance, because the forest serves as a water control, climate control, pest control and living places of animal pollinators such as honey bees, beetles, birds, bats [4].
Utilization of natural resources in ways that transcend natural recovery potential affects the availability of environmental services in the future. If it continues, the existence of environmental assets will deteriorate sharply and the environmental services currently acquired will be lost or costly. In the end, it will harm human welfare [5]. Therefore, to support life and improve the welfare of human life, the utilization of environmental services needs to be further improved to be balanced by the utilization of natural extraction, to ensure the future of mankind.

One of the important forest areas is the protected forest. According to its definition, forest protection is a forest area that has a basic function as a protective system of life buffer to regulate water, prevent flooding, erosion control, prevent seawater intrusion, and maintain soil fertility [6]. From this definition, it appears that the potential contained by the protected forest is so great, but as long as this protected forest is including the neglected area, because it is not allowed to be exploited considering the important function is as a protection of the buffer system of life.

Seeing the potential of environmental services to support human survival, the Indonesian Government through the Ministry of Forestry issued regulation of the Minister of 
Forestry No. P. 22/Menhut-II/2012 on the business activities guidelines on the use of nature tourism environmental services in protected forest. Protected forest is a limited area, but has a lot of potential that will be redundant if not utilized optimally. With the use of environmental services, it is possible to use protected forests that have been neglected to increase the state income and the welfare of the people, especially those domiciled around the protected forest. By utilizing the environmental services many benefits are gained without damaging the environment and do not reduce its main function. When the utilization of protected forest can be utilized through environmental services with natural tourism, as an example, it will be more and more limited area that can be developed through environmental services [7].

Based on the explanation above, this research is done with the purpose of analyzing the problems of potential environmental services utilization undertaken by the community.

\section{METHODS}

This research was carried out around the city of Ternate protected forest area The selection of this location was done intentionally (purposive) with the consideration of accessibility that the area is the location of the environmental service provider model. The retrieval of landscape data is based on the methods of the Bureau Lands of Managements, which is a method of landscape assessment for the visual potential based on the central point of attention with parameters including land shape, vegetation, water, color, scenery, scarcity, and structural modification.

This primary data was obtained through questionnaires and in-depth in-depth interviews (in-depth interviews) with respondents and is expected to be a supporter to find out the quality and determine the type of tourism according to the assessment based on criteria set by Pott modified by Fandeli [8].

\section{A. Processing methods and Data analysis}

Data analysis is done by a quantitative descriptive method. Analysis of the quality of travel products is done by the model of delivery by way of scoring. The values obtained from each of the parameters that have been entered in the table are aggregated. From the amount of value obtained it can be known whether the environmental services are potential or potential not to be developed into natural attractions.

To determine the potential class of each tourist object, it is calculated using a specific statistical formula [10]. The following phases of the calculation:

1. Determine the potential class interval

$$
\begin{aligned}
& \text { Variance }\left(S^{2}\right) \\
& =\frac{\sum(\mathrm{x}-\overline{\mathrm{x}})^{2}}{n-1} \\
& \text { Standard deviation }(\mathrm{Sd})=\sqrt{\frac{\sum(\mathrm{x}-\overline{\mathrm{x}})^{2}}{\mathrm{n}-1}}
\end{aligned}
$$

1. Determine the potential class

$$
\begin{array}{ll}
\text { High } & :>\overline{\mathrm{x}}+\frac{\mathrm{sd}}{2} \ldots \ldots \ldots \ldots(1) \\
\text { Medium } & :\left(\overline{\mathrm{x}}-\frac{\mathrm{sd}}{2}\right)-\left(\overline{\mathrm{x}}+\frac{\mathrm{sd}}{2}\right) \ldots \ldots(2) \\
\text { low } & :<\overline{\mathrm{x}}-\frac{\mathrm{sd}}{2} \\
\text { Information: } & \\
& \text { X (total score of each Tourist Attraction Object) } ; \bar{x} \\
& \text { (average tourist attraction object score value); } \\
& n \text { (number of variables) }
\end{array}
$$

Analysis of landscape quality based on landscape assessment criteria for nature tourism made by Bureau of Land Management is summed [11], then the quality of the landscape is grouped as follows:

1. Grades 19-33, including class A (high quality)

2. Grades $12-18$, including class B (medium quality)

3. Grades $0-11$, including class C (low quality)

\section{RESULTS AND DISCUSSION}

\section{A. The Quality of Tourism Products in Batu Angus and} Sulamadaha Beach

The components of tourism products include natural attractions, accessibility, amenities, and institutions. Flora, fauna, and landscape are supporting factors for tourism products [12]. The core and supporting factors of a tourism product are interrelated and support each other in attracting visitors

The assessment of tourism research variables to produce a mathematical analysis, then the observations that were originally qualitative must be converted into mathematical numbers with a scoring method [13]. The data that has been converted will be added up and calculated to determine each potential class. After the scores are added, using a systematic calculation a standard deviation is obtained. The score and standard deviation which qualitatively will determine the potential class of Batu Angus and Sulamadaha Beach attractions.

Table 1. Class Division potential Tourism Objects

\begin{tabular}{|c|c|c|}
\hline No & Amount & Potential class Division \\
\hline 1 & $>34$ & High \\
\hline 2 & $33-34$ & Medium \\
\hline 3 & $<33$ & Low \\
\hline
\end{tabular}

Based on data from observations of tourist attraction objects in Batu Angus and Sulamadaha Beach it is known that Batu Angus (score 33) is included in the Medium 
quality criteria and Sulamadaha Beach (score 36) is included in the High-quality criteria.

\section{B. Potential Tourism Objects of Batu Angus and Sulamadaha Beach}

Based on observations that have been made, the results of the assessment of research variables Batu Angus tourism objects are described in the following table

Table 2. Potential Scoring Results for Batu Angus Tourism Object

\begin{tabular}{|l|l|c|}
\hline No & $\begin{array}{l}\text { Indicator / Variable } \\
\text { Potential of Tourism } \\
\text { Object }\end{array}$ & Score Results \\
\hline 1 & $\begin{array}{l}\text { Quality of Tourism } \\
\text { Object }\end{array}$ & 12 \\
\hline 2 & Accessibility & 5 \\
\hline 3 & Amenities & 11 \\
\hline 4 & Institutional & 33 \\
\hline & Total & \\
\hline
\end{tabular}

\section{Quality of Tourism Object}

Batu Angus tourism object is a stretch of rock that looks like a scorch burned. The expanse of stone stretches from the foot of Mount Gamalama to the beach. The Angus stone is the remnant of the eruption of Mount Gamalama in the 17th century and the lava that has been turned into stone looks like a newly burned stone. Named Angus Stone because frozen lava has a dark black color. At first glance, this stone is just ordinary, but if you look at it as a whole will see another beauty of this collection of stones. A high level of authenticity can be a special attraction for a tourist attraction (score 4).

Uniqueness is defined as a combination of scarcity and attractiveness that is inherent in a particular tourist attraction [14]. Batu Angus can be said to have its own uniqueness, this can be seen from the condition of the structure of the rocks and landscape contained in the area of the tourist attraction (score 2).

Based on observations, Batu Angus can be enjoyed its beauty directly. The relaxed atmosphere in nature can also still be felt in this tourist area (score 2). Integrity, Like Sulamadaha Beach, Batu Angus tourism objects have not experienced significant structural modifications to the landscape. (score 2). Availability of development land, Batu Angus Tourism has an area of 40 hectares. At present, the area is still quite small but it is still possible to accommodate tourists visiting for now (score 1).

\section{Accessibility of Batu Angus Tourism Objects.}

Accessibility is a way to provide public transportation facilities for tourists that affect the cost, time and distance [15]. Batu Angus Tourism Locations can be reached using private transportation. Transportation is only available if you use rental services if you are going to a tourist attraction (score 1)

\section{Amenities}

Amenities is an infrastructure that is not directly related to tourism but is often a part of tourist needs [16]. At present, the Batu Angus Air tourism object area has shelters, signs or warning boards and public toilets to support the needs of tourists. However, the conditions are still adjusted to the budget and environmental conditions (score 5).

\section{Institutional.}

Institution in nature tourism is very complicated and important in developing tourism objects. In addition, careful planning and participation of the right parties will reduce conflicts that lead to developments in tourism. In addition, the preservation of the Tourism Attraction Object must also be maintained from tourism products that serve services (services) where the destination must be equipped with cement that tourists might be able to provide [17].

Batu Angus Tourism is currently in the Regional Technical Implementation Unit of the North Maluku Province Tourism Office. The institutional structure in this tourism is still inadequate because the development of the management of these attractions is still being developed (score 3).

\section{The Quality of Batu Angus Tourism Objects}

Based on observations that have been made, the results of research on the research object of the Batu Angus attraction are described in the following table:

Table 3. Potential Scoring Results for Batu Angus Tourism Object

\begin{tabular}{|l|l|c|}
\hline No & $\begin{array}{l}\text { Indicator / Variable } \\
\text { Potential of Tourism } \\
\text { Object }\end{array}$ & Score Results \\
\hline 1 & $\begin{array}{l}\text { Quality of Tourism } \\
\text { Object }\end{array}$ & 12 \\
\hline 2 & Accessibility & 5 \\
\hline 3 & Amenities & 5 \\
\hline 4 & Institutional & 11 \\
\hline & Total & 33 \\
\hline
\end{tabular}

\section{Quality of Sulamadaha Beach Tourism Object}

Sulamadaha Beach is a marine tourism area located in Sulamadaha Village, West Ternate District, Ternate City, North Maluku Province. Sulamadaha Beach is located only about 300 meters from the Village of Sulamadaha. Based on observations that have been made, the results of the assessment of research variables in the Sulamadaha beach tourism object are described in Table 4 below: 


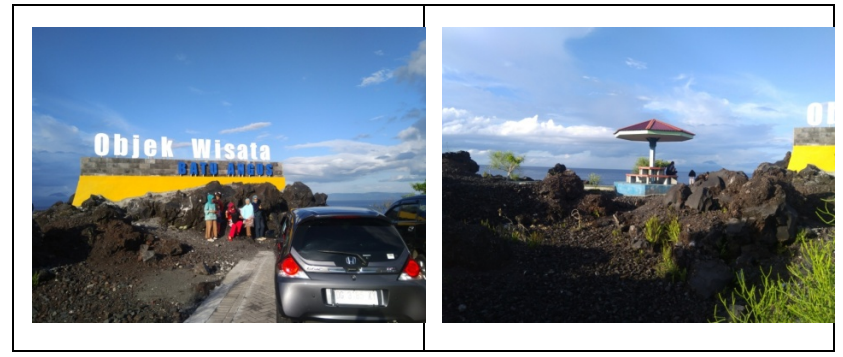

Figure 1. Batu Angus Landscape

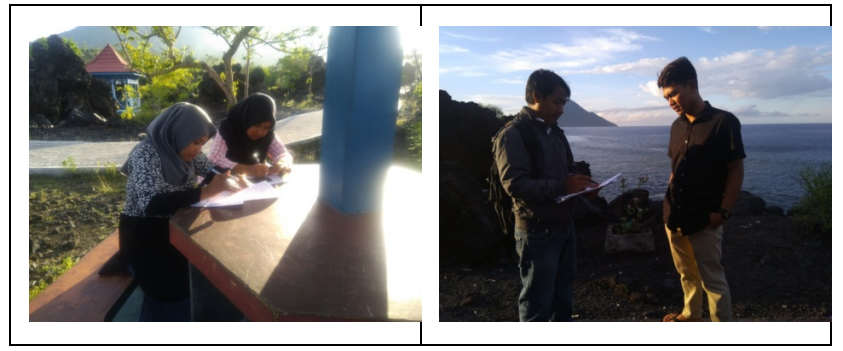

Figure 2. Completion of Questionnaire and Interview by Visitors

Table 4. Potential Scoring Results of Sulamadaha Beach tourism object

\begin{tabular}{|l|l|c|}
\hline No & $\begin{array}{l}\text { Indicator / Variable } \\
\text { Potential of Tourism Object }\end{array}$ & $\begin{array}{c}\text { Score } \\
\text { Results }\end{array}$ \\
\hline 1 & Quality of Tourism Object & 14 \\
\hline 2 & Accessibility & 5 \\
\hline 3 & Amenities & 6 \\
\hline 4 & Institutional & 11 \\
\hline & Total & 36 \\
\hline
\end{tabular}

\section{Quality of Tourism Object}

Uniqueness is defined as a combination of scarcity and attractiveness that is inherent in a particular tourist attraction [14]. The depth of Sulamadaha waters varies greatly from $2 \mathrm{~m}$ to $25 \mathrm{~m}$ so that the seawater looks colorful in the color spectrum of mixing green and blue. Sulamadaha beach is dominated by scales or radii with various marine biota such as sea lilies, sea urchins, eels and some ornamental fishes such as yellow tangs, butterflyfish, and Abel angelfish. Sulamadaha beach some time is often used as a place to cross the wooden relation between Ternate Island and Hiri Island when the waves tend to be high. The infrastructure of the tourist area is one factor in the success of a tourism activity. The better and more complete infrastructure in the tourist area, the smoother the walking activities. (score 2).

The beauty of the Sulamadaha Beach tourism area consists of two spots including the black sand beach and the bay spot which is commonly known by the name Hol Sulamadaha which is shown in Figure 4. According to Ternate City Regulation No. 2 of 2012, the Hol Sulamadaha spot is included in the marine/watershed conservation area in the form of coral reef conservation which also functions as a tourism designation area. Sulamadaha Beach tourism area applies one gate and single pricing. This means that each visitor can only come through one entrance access and visitors are only charged a one-time entry fee to the two spots available in the tourist area.

Sulamadaha Beach has an infrastructure similar to the tourist area of the Coast in Indonesia, more precisely that distinguishes and becomes an attraction consisting of a physical tourism area on the Sulamadaha Beach has black sand and a direct view overlooking Hiri Island which is one of a group of small islands in North Maluku Province and has a place which is one of the best coral reefs in Ternate City (score 3).

The condition of infrastructure in the tourist area of Sulamadaha Beach, in general, is quite good but there are some infrastructures that are not maintained or even damaged. Infrastructure in the tourist area is dominated by black sand beach spots. Meanwhile, some infrastructure in Hol Sulamadaha was built at the initiation of the local community. Based on field observations, the condition of toilets in both spots of the tourist area tends to be poorly maintained and the numbers are still minimal, causing visitors to have to queue. Some infrastructure in the tourist area is paid infrastructure such as a gazebo which is charged at a rate of $\mathrm{Rp} \mathrm{50,000} \mathrm{in} \mathrm{disposables} \mathrm{and} \mathrm{toilets} \mathrm{in}$ the amount of $\operatorname{Rp} 2,000$ one-use (score 3 )

\section{Accessibility of Batu Angus Tourism Objects}

Accessibility to the Sulamadaha Coast area can be in two ways, namely through the South Ternate District (the lower road) and through the North Ternate District (the upper road). The average travel time of both accesses is 1 hour and 30 minutes, respectively. Modes of transportation that can be used to reach the Sulamadaha Coast tourist area are private transportation. Based on field facts, the majority of visitors prefer to use private vehicles or rent vehicles either two-wheeled or four-wheeled. (score 1).

\section{Amenities}

Currently, the Sulamadaha Beach tourism object area has shelters, signs or warning boards and public toilets to support the needs of tourists. However, the conditions are still adjusted to the budget and the surrounding environment conditions (score 5).

\section{Institutional}

Based on the Decree of the Mayor of Ternate, it was determined that the management of the Sulamadaha Beach Tourism Area is managed entirely under the auspices of the Ternate City Culture and Tourism Office. The main task of the Office of Culture and Tourism of the City of Ternate based on Ternate Mayor Regulation No.19 of 2008 is to carry out the authority of regional autonomy in the context of carrying out the tasks of decentralization in 
the field of culture and tourism. In addition, in managing the Sulamadaha Beach, the Disbudpar Ternate City coordinates with several agencies in carrying out its management. For example, in setting the annual tourism revenue target implemented by the Ternate City Dispenda and the development of public infrastructure by the Ternate City Public Works Agency. (score 3).

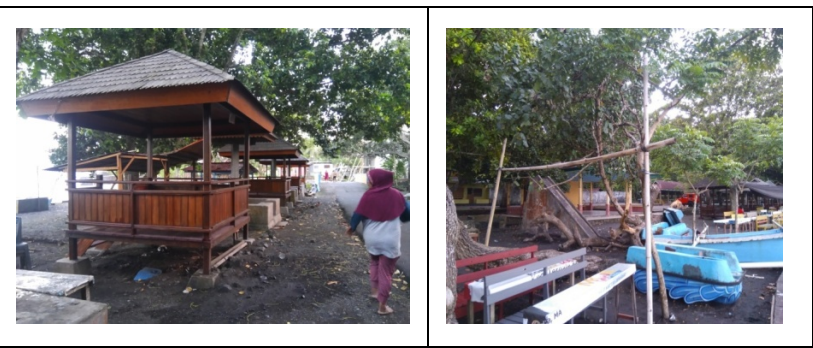

Figure 3. Sulamadaha Beach Shelter

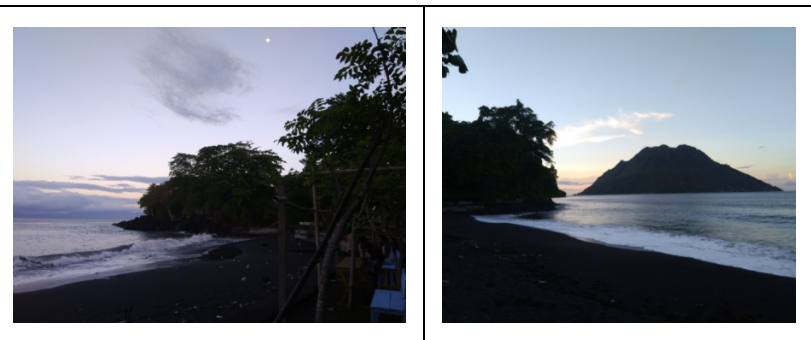

Figure 4. Sulamadaha Beach Landscape

\section{Landscape Quality}

Based on observations and assessments that refer to the parameters of the Bureau of Land Management, Angus stone tourism objects are included in class B with a value of 17 (medium quality) and Sulamadaha Beach included in class A, with a value of 18 (moderate quality). A description of the results of the study is described in the following table

Table 5. Landscape Potential Assessment Results

\begin{tabular}{|l|l|c|c|}
\hline \multirow{2}{*}{ No } & \multicolumn{1}{|c|}{$\begin{array}{c}\text { Landscape } \\
\text { components }\end{array}$} & \multicolumn{2}{c|}{$\begin{array}{c}\text { Landscaping } \\
\text { Potential on-site }\end{array}$} \\
\cline { 3 - 4 } & \multicolumn{2}{|c|}{$\begin{array}{c}\text { Batu } \\
\text { Angus }\end{array}$} & $\begin{array}{c}\text { Sulamadaha } \\
\text { Beach }\end{array}$ \\
\hline 1 & Landform & 3 & 3 \\
\hline 2 & Vegetation & 1 & 3 \\
\hline 3 & Water & 1 & 2 \\
\hline 4 & Color surrounding & 3 & 3 \\
\hline 5 & $\begin{array}{l}\text { The } \\
\text { landscape }\end{array}$ & 4 & 3 \\
\hline 6 & Scarcity & 2 & 2 \\
\hline 7 & Modification & 16 & 18 \\
\hline & Total & & \\
\hline
\end{tabular}

\section{CONCLUSION}

Batu Angus tourism products and Sulamadaha Beach are included in Medium quality, based on observations and assessments that refer to the parameters of the Bureau of Land Management. Batu Angus Tourism Object is included in class B with a value of 17 (medium quality) and Sulamadaha Beach included in class A with a value of 18 (moderate quality). Seen from the aspect of the quality of the tourist attraction which consists of elements of authenticity, uniqueness, beauty, integrity, and availability of development land, and institutional aspects. Even though the current management has not been maximized, it has obtained permits and support from the Forestry Service in developing tourism. This area has a slightly reduced quality aspect of tourist objects due to visiting tourist activities such as vandalism, damage to the trail, and the accumulation of garbage.

\section{ACKNOWLEDGMENT}

This research was supported by the University of Khairun DIPA funding in 2018. The author would like to thank the manager of the Batu Angus and Sulamadaha Beach attractions and the visitors who were willing to be interviewed

\section{REFERENCES}

[1] S. Nambiar, and I. Ferguson, eds. New forests: wood production and environmental services. CSIRO Publishing, 2005.

[2] R. B. Howarth, and S. Farber, "Accounting for the value of ecosystem services," Ecological Economics, vol. 41, no. 3, June 2002, pp. 421429.

[3] J.P Barde and D.W Pearce, "Valuing the environment, six case studies," Earthscan publications Ltd London, 1991.

[4] T.D. Schowalter, J.A. Noriega, and T. Tscharntke, "Insect effects on ecosystem servicesIntroduction," basic and applied ecology, Vol 26, pp. 1-7, February 2018

[5] RUPES, "Konsep Jasa Lingkungan dan Pembayaran Jasa Lingkungan di Indonesia," World Agroforestry Centre, Bogor, 2009

[6] Peraturan Menteri Kehutanan Republik Indonesia No. P.22/Menhut-II/2012 tentang pedoman kegiatan usaha pemanfaatan jasa lingkungan wisata alam pada hutan lindung

[7] Roldan Muradian, Esteve Corbera, Unai Pascual, Nicolás Kosoy, and Peter H. May, "Reconciling theory and practice: An alternative conceptual framework for understanding payments for environmental services", Ecological Economics, vol. 69, 2010 pp. 1202-1208 
[8] C. Fandeli, "Perencanaan kepariwisataan alam," Fakultas Kehutanan UGM, Yogyakarta, 2002.

[9] A. Wijayanti, J. Damanik, C. Fandeli, and Sudarmadji, "Analysis of supply and demand to enhance educational tourism experience in the smart park of Yogyakarta, Indonesia," Economies, vol 5 (42), pp. 2-13, November 2017

[10] H. Hassani , M. Ghodsi, And Garethhowell, "A note on standard deviation and standard error," teaching Mathematics and Its Applications, vol 29, pp. 108-112, March 2010

[11] Burau of Land Management, "Visual Resource Management," Departement of Interior USA, US Government Printing Office, Washington DC, 1986.

[12] Rusita, R. Walimbo, Y. Sari, M. Yanti, "Studi potensi objek dan daya tarik wisata alam air terjun wiyono di taman hutan raya wan abdul rahman Provinsi Lampung," Keilmuan dan Aplikasi Teknik, Desember 2016, vol 17, no 2, pp.165-186.
[13] M.F. Cracolici, P. Nijkamp, and P. Rietveld. "Assessment of tourism competitiveness by analyzing destination efficiency," Tourism Economics, vol 14, no. 2, June 2008, pp. 325-342.

[14] Y. Ram, P. Björk, and A. Weidenfeld, "Authenticity and place attachment of major visitor attractions," Tourism Management, vol. 52, February 2016, pp. 110-122.

[15] T. Litman, "Measuring transportation," Traffic, mobility and accessibility, ITE Journal, Vol 73, no.10, 2003, pp. 28-32.

[16] N. Mistriani, R.P. Ardi, and H. Listyorini, "Development Tourism Village Strategy Of Samiran As A Creative Tourism Model In Central Java." 2nd International Conference on Tourism, Gastronomy, and Tourist Destination (ICTGTD 2018). Atlantis Press, 2018.

[17] R.V. Bianchi, "Place and power in tourism development: tracing the complex articulations of community and locality," Pasos. vol 1, no. 1, 2003, pp. 13-32. 